\title{
Performance Analysis of Students Through Critical Thinking Ability Based on Mathematic Ability
}

\author{
Qurrota A'yun ${ }^{1}$, Rosita Yanuarti ${ }^{1}$, Dimas Anditha Cahyo Sujiwo ${ }^{2}$ \\ ${ }^{1}$ Department of Informatics Engineering, University of Muhammadiyah Jember, Jember, Indonesia, 68121 \\ ${ }^{2}$ Department of Mathematics Education, IKIP PGRI Jember, Jember, Indonesia, 68121 \\ *Corresponding author: qurrota.ayun@unmuhjember.ac.id | Phone Number: +6282231308136
}

\section{ARTICLE HISTORY}

Received : 11 August 2020

Revised : 11 March 2021

Accepted : 10 April 2021

\section{KEYWORDS}

Critical Thinking Skills; Level of Performance;

\begin{abstract}
The standard of critical thinking in this study, namely: first, interpretation is on a problem can showing / writing what they know and what is asked about the problem correctly; second, analysis is the activity of identifying the relationship between statements, questions and concepts in a problem through making mathematical models and accompanied by the right reasons; third, evaluation is the right strategy in solving problems and fourth, conclusion is accuracy in drawing conclusions from what is asked. While the type of research used is descriptive qualitative type. The instruments used were interview guidelines and test questions. The interview used is a structured interview and the test used in the form of a math problem test with derived application material consisting of 3 problem descriptions with material that has been received by students. Student performance levels in this study are at the Apprentice level and the Novice level. The acquisition of data at the Apprentice level the average value is different, this is because the acquisition of data on each indicator is different overall. This is because the subject is not accustomed to or accustomed to working on open questions or also problem stories/problems. Student performance levels in this study are at the Apprentice level and the Novice level. The acquisition of data at the Apprentice level the average value is different, this is because the acquisition of data on each indicator is different overall. This is because the subject is not accustomed to or accustomed to working on open questions or also problem stories/problems.
\end{abstract}

This is an open access article under the CC-BY-SA license.

\section{INTRODUCTION}

In terms of education, it is all aspects of activities that have a positive impact on all subjects and objects in education. Activities in education are not just the delivery of subject matter such as providing explanations to students, but there are many basic things that need to be considered such as guidance and direction, as well as instructions for each student (Fattah, 2003; Tilaar, 2012; Alwasilah, 2012; Sauri,2006). Activities like this are things that can affect aspects of knowledge and motivation of students in carrying out learning activities. (Sardiman, 2007; Wardati \& Jauhar, 2011; Sukardi \& Kusmawati, 2008; Sumarwiyah, 2009). With the development of an era, of course education will also continue to develop over time, this can be exemplified and found in terms of science or technology. Technology that has developed drastically has certainly entered our lives. This needs to be considered by all education observers as the development of a technology that has a role in increasing capabilities in all fields in general.

Learning in terms is known as two-way communication activities by involving support for each student in order to achieve learning goals and change behavior in a positive direction (Mulyadi, 2010; Mulyasa, 2007). In their duties, educators need to develop the basic abilities of their students, such as the abilities contained in three indicators, namely intellectual, psychomotor and affective abilities. In developing these abilities, of course there are many factors that influence it (Yusuf, 2005; Siswanto, 2016). Therefore educators need to prepare what activities will be carried out by students and the need to prepare as early as possible by paying attention to the many factors that influence it. The statement above is in accordance with the opinion of Sakerebau (2018) which clearly explains that many factors influence a person in learning, where these factors are classified into internal factors, which come from within a person consisting of psychological, fatigue, and physical items, while other factors, namely external factors are those that come from outside the person such as parents, educators, and the surrounding community.

In learning mathematics, which is part of a scientific discipline, it has a major role in the development of science and also in the field of technology, this is because mathematics is said to be one of the sciences that underlie other sciences (Shadiq, 2014; Sumarmo, 2007; Mandur, 2013; Jihad, 2008). In studying mathematics, we can learn to develop meticulous and accurate aspects, we can also improve 
critical and logical thinking skills, reasoning and can be positive, creative, responsible, and the ability to work with peers (Ismaimuza, 2010; Riyanto, 2010; Trianto, 2010; Isjoni, 2009; Dwitagama and Wijaya, 2012; Haryani, 2012; Julita). This is in accordance with Suherman et al (2003: 56) which states that there are three functions in learning mathematics, namely patterns of thought, tools, and knowledge. Furthermore, Vincent (Dahlan, 2017) explains that thinking is any mental activity that can help formulate or solve a problem, make decisions or fulfill the desire to understand something. Not a few students argue that it is difficult to learn and understand mathematics subjects because the object of study studied in mathematics is abstract and moreover learning is only from educators. Memory limitations are also the cause of students to memorize mathematical formulas that are considered meaningful. This kind of thing can have an impact on mathematics which is still seen as a difficult subject for students and society in general (Muijs \& Reynolds, 2005). The thinking ability of each individual is certainly not the same, so each individual needs to practice and develop their abilities in studying mathematics subjects. This way of learning that is carried out by students certainly needs a change, namely by increasing their thinking skills, one of which is critical thinking.

Choy \& Cheah (2009) define critical thinking as complex which requires a high level of cognitive processing information. Furthermore, Ennis (2011) explains that critical thinking is the ability to think reflective and reasoned which is focused on what is believed or done. Students can think critically with a skill through the results of activities to analyze and prove the truth. According to Fisher (2009), it explains that critical thinking is a skill in thinking about everything in an appropriate way in interpreting and evaluating activities such as observation, interaction with various other sources of information. Critical thinking carried out by students in the form of questioning questions, answering logically, finding information in an efficient time. A person's ability can be improved with regular practice in solving math problems. The maximum effort that must be done is to give students experience knowledge so that students' performance abilities will increase. To find out this, a method is needed that can inform learning outcomes, namely the achievement of student competencies, which is called an assessment. The appropriate form of assessment is student performance assessment. While Arifin (2012) performance appraisal is a way of assessing the level of mastery of students' skills through performance tests or demonstrations or real work practices. The level of student performance consists of four levels with reference to the level set by Exemplars. The four levels are Novice, Apprentice, Practitioner, and Expert.

Dahlan (2017) explained that the four levels of performance appraisal for students were in full according to the NCTM standard. The following is the explanation: 1) Novice, students have a strategy in solving problems that contain problems, participants do not provide logical explanations in mathematical concepts related to the process of proof, are unable to communicate ideas in their thinking, are unable to connect old knowledge with new ones so that little experience, and unable to construct mathematical concepts; 2) Apprentice, at this level, students can be said to have been able to have or carry out a correct strategy to solve a problem, can provide reasons and the process of proof can be said to be logical even though it is not yet orderly, able to communicate ideas partially, can associate the knowledge they have with the new knowledge they get while studying the lessons they follow, and are able to connect mathematical concepts but are still part of the process; 3) Practitioner, students have begun to be able to have the correct strategy to solve problems, reasons and the process of proof have started to be logical, able to partially communicate ideas, able to connect old knowledge with new ones, and able to construct mathematical and scientific concepts but still part of the process construction; 4) Expert, this level shows that students have started to be able to have the right strategy to solve problems, the reasons and the proof process have started to be logical, able to communicate complete ideas, able to connect old knowledge with new ones, and able to construct mathematical and scientific concepts. This research is based on the level set by Exemplars. So that researchers will observe student performance levels, namely: Novice, Apprentice, Practitioner and Expert. To find out the level of students in this study is to connect each level with the predetermined standard indicators of thinking. Performance level category based on NCTM stipulations adopted by Dahlan, (2017).

Tabel 2. Performance level category

\begin{tabular}{cc}
\hline Score & Performance level \\
\hline$x=4$ & Expert \\
\hline $3 \leq x<4$ & Practitioner \\
\hline $2 \leq x<3$ & Apprentice \\
\hline $1 \leq x<2$ & Novice \\
\hline
\end{tabular}

\section{METHODS}

This type of descriptive qualitative research is used in this study Researchers describe the performance level of Information Technology students. In other words, it can be said that the researcher describes the level of performance of this Information Technology student based on the student's critical thinking ability in solving math problems given during research activities. The researcher also described the level of student performance in critical thinking in solving problems in the form of problems. The researcher checks and reports the results of the student's problem solving by matching the results of the student's answers with the criterion of critical thinking.

The data in the study were interview guidelines that would be applied to students and test questions that would be carried out by six selected students majoring in Information Technology class A Muhammadiyah University of Jember which were categorized as high, medium, and low. Data obtained in the form of test results and interviews. The test for performance levels is based on students' critical thinking skills. The research subjects were Muhammadiyah Jember Information Technology students. Subject taking was obtained from previous students' scores to group students with high, medium and low abilities and continued by selecting two students from each category. From the test activities given, then conducting interviews with each student as the research subject. Taking two students of Information Technology class A Muhammadiyah University of Jember in each of these categories aims to determine whether students in the same category are at the same level or not. So that in this study the researcher took as many as 6 subjects with two high category students, two medium category students, and two low category students who would be analyzed for their performance levels based on their critical thinking skills in solving math problems that had been prepared before the activity. 
The test used is in the form of a math problem test with derivative application material consisting of 3 description questions with material that has been received by students. Each question will test the criteria or indicators of student performance assessment based on critical thinking skills. The purpose of working on these questions is to make sure that the student can work on the questions given with the same type. The interview activity was carried out after giving the final test questions. To avoid the same answer, interviews were carried out alternately for each ability group and carried out individually. The type of interview used is a structured interview because the guidelines were prepared from the start. The analysis was carried out in critical thinking skills, namely the analysis of the test results obtained from the answer sheet. Student answers are analyzed with an assessment sheet based on standard critical thinking indicators, which will then be categorized into performance levels in accordance with the scoring guidelines for the performance levels that have been made, scoring on student work results on test questions is adjusted to indicator achievement. After giving scores on the students 'work on the test questions, an interview was conducted which aimed to see whether the students' answers were consistent between the answers on the test questions and during the interviews.

\section{RESULTS AND DISCUSSION}

In the implementation of this research, the research instruments that will be used are validated first by the experts in their fields. There are three validators who will provide an assessment of the instruments to be used. By carrying out this validation activity, it is hoped that the level of validity of this research instrument can be measured so that it can be used properly. The instruments that will be used are the instrument test questions and interview instruments. The following are the values of the three validators. The results of validator 1 indicate that the test questions instrument is in the range of 2.5833333333 or $\mathrm{Va}=2.5833333333$. These results indicate that the value of validator 1 for the question instrument is in the valid criteria. The result of validator 2 shows that the result of the instrument validation test is 2.6666666667 or $\mathrm{Va}$ $=2.6666666667$. While validator 3 shows the results of the instrument validation test are 2.6666666667 or $\mathrm{Va}=$ 2.6666666667. So that the average validation result of the three validators for the test instrument is 2.638888889 . According to the instrument validity criteria, then the test instrument is valid in the $2.5<\mathrm{V}_{\mathrm{a}}<3$ category range. Furthermore, in the interview instrument, the average value of the three validators was obtained by 2.5833333333 . The details of each validator for the validation of the guideline instrument are as follows. validator 1 gives a score of 2.5 for the interview instrument, the value of the validator 2 is 2.75 , and the value of the validator 3 is 2.5 . So that the average obtained in the validation of the interview instrument for the three validators is 2.5833333333 . This value is in the valid category and falls into the $2.5<\mathrm{Va}<3$ category. research can be used for research activities.

Of the 6 students who were the subject, the level of performance of each student was obtained by different indicators of achievement. This student performance level is based on their critical thinking skills which are classified into two levels, namely the apprentice level and the novice level. This leveling grouping is based on an analysis of student answers in solving a problem. In the results of this leveling, students are dominant at the apprentice level, through this research it is hoped that students can hone their critical thinking skills in solving problems. Critical thinking can be said as thinking that processes and results by analyzing and evaluating them. This certainly shows that students can think critically with their own skills by analyzing and proving the truth. The following is the result of the percentage of students' critical thinking on each predetermined indicator.

Tabel 2. The average gain from the performance level indicator

\begin{tabular}{cccc}
\hline Item & Name & Average & Category \\
\hline 1 & $\mathrm{BE}$ & 2,111111111 & Apprentice \\
\hline 2 & $\mathrm{AL}$ & 2,111111111 & Apprentice \\
\hline 3 & $\mathrm{AA}$ & 2,851851852 & Apprentice \\
\hline 4 & $\mathrm{AF}$ & 2,518518519 & Apprentice \\
\hline 5 & $\mathrm{AX}$ & 1,740740741 & Novice \\
\hline 6 & $\mathrm{AU}$ & 1,666666667 & Novice \\
\hline
\end{tabular}

Based on the table above, it shows that the results of low-ability critical thinking skills appear to be at the novice level stage. Medium abilities are at the apprentice level, as well as high abilities are at the apprentice level. Based on this data, it shows that students have different ability to think. Students need to be accustomed to being given problems that require working on questions that have a creative thinking level. In research activities, it is at the interpretation stage where students are asked to understand the questions related to the problem. This stage requires students to understand the problem, students have the ability to think in different ways.

For the two low-category students, one of the students was not clear or did not understand the problem. This means that the student is not precise or incomplete in writing what he knows and the questions asked. This was reinforced during interviews, students were not yet precise or clear in terms of describing a problem. One of the other students was able to say that he understood enough about the problem. This is evidenced in the answer sheet, which shows that the student can write down what is known and what is being asked about the question. In the interview activity too, the student's statement can be said to be consistent with the answer sheet. With consistency between student answer sheets in the low category and what was conveyed during the interview, AU students are at the novice level because most of them do not fulfill all critical thinking indicators, while AX students are also at the novice level, but the average results of the scores critical thinking indicator is different from AU. AU obtained an average value of 1.6666666667 in the novice level category and AX got a score of 1.740740741 which is also at the novice level. In other words, there is a difference in the results of the average acquisition of critical thinking indicators for students with the low category, this is because the data acquisition for each indicator is different as a whole.

Students with moderate ability at this critical thinking stage, it can be said that they have understood the problem well, this is known when they can do or write things that are known, overall there are still some errors and inaccuracies. another thing in the process, students in the medium category are good enough in presenting a problem that is in the problem in clear language. In the interview activity with students in the medium category, as a whole the students explained what was asked in the interview according to what they wrote in their respective answer sheets. In terms of writing down the student's understanding of the questions, the student can rewrite the answers to what is known and 
what is asked in the questions. Although in writing a strategy plan for solving and solving problems, there are still things that are unclear and inaccurate. Therefore, this student is expected to be careful in solving all the questions given in the future. Overall, this medium category student is quite good at working on questions and interview activities. This is shown in the triangulation activity of the test and interview method which shows that each student with the moderate category is very consistent between the answer sheet and the student's answer during the interview. The validity of the data through this triangulation shows the validity of the data results. In the middle category students indicate that the two students are at the Apprentice level, but the average obtained from the two students is different, this is because the data acquisition of the two students on each indicator of critical thinking is different as a whole.

Students with high abilities at this critical thinking stage, it can be said that students with high categories already understand the questions well. Students are also able to write down the problem questions by writing down what is written on the questions clearly. Students are also able to plan the problem solving properly and also in accordance with the answers to solving the questions. However, in the indicators of writing another alternative way, students have not been able to write well. So that in this indicator students get a score of 1 . While in making conclusions about solving the questions, the two students are very clear and can be said to be good at making conclusions, the reasons given in the conclusions also reflect correct problem solving. Then discussing interview activities with the two students with this high category. The explanation of the things conveyed in the interview activities by the two students was very consistent with the answer sheets they worked on. Overall students are in the high category both in solving problems on the questions and in delivering them in interview activities. This is because in the data validity activity, the triangulation of the test and interview method produces appropriate results, meaning that each student in the high category is so consistent between the answer sheet and the delivery that was raised by the student during the interview activity. With the results of data validity through this triangulation, it can be said that the results of the data obtained from this method are "valid". In high category students, both students are at the Apprentice level, but the average obtained from the two students is different, this is because the data acquisition of the two students on each indicator of critical thinking is different as a whole.

\section{CONCLUSION}

Based on the discussion and analysis results, it can be concluded that the level of student performance in the critical thinking ability of Information Technology students shows at the Apprentice level and the Novice level. Of the six existing subjects, 2 subjects are at the Novice level. This subject is a subject with low ability. While at the Apprentice level there are four subjects. The four subjects have different abilities, namely two subjects with moderate ability and the other two subjects are subjects with high abilities. However, in this category with the same Apprentice level the average obtained by the four subjects is different, this is because the data obtained by these four subjects on each indicator are different as a whole. In this study, none of the six subjects were at the critical thinking level category with the Practitioner level and the expert level. This is because the subject is not accustomed or accustomed to working on open questions or story questions/problems.

\section{REFERENCES}

A.M, Sardiman. (2007). Teaching and Learning Interaction and Motivation. Jakarta: PT Raja Grafindo Persada.

Alwasilah, A,c. (2012). Anyway Engineering Literacy. Bandung: PT Kiblat Buku Utama.

Arifin, Zainal. (2012). Learning Evaluation. Bandung : PT. Remaja Rosdakarya.

Choy, S. C., \& Cheah, P. K. (2009). Teacher Perception of Critical Thinking Among Students and Its Influence on Higher Education. International Journal of Teaching and Learning in Higher Education, 20(2), 198-206. Retrieved from:

http:/ /www.isetl.org/ijtlhe/pdf/IJTLHE336.pdf.

Ennis, R.H. (2011). The Nature of Critical Thinking:An Outline of Critical Thinking Disposition and Abilities. Last Revised. Emeritus Proffessor: University of Illinois

Dahlan, A. (2017). Leveling of Student Performance Based on Critical Thinking Ability of Class VII Students of MTs Negeri Jember 1 Filial in Solving Mathematical Problems Related to the Coffee Theme. Jurnal Matematika. Jember: Universitas Jember.

Dwitagama, D andWijaya, K. (2012). Get to know Classroom Action Research. Jakarta: Indeks.

Fattah, N. (2003). Concept of School Based Management and School Board. Bandung : Pustaka Bani .

Fisher, A. (2009). Critical Thinking: An Introduction. Jakarta: Erlangga.

Haryani, Desti. (2012). Shaping Critical Thinking Students through Mathematics Learning. Proceedings of the National Seminar on Mathematics and Mathematics Education, Nov:10. Yogyakarta.

Isjoni.(2009)."Cooperative Learning Increases Communication Intelligence among Students". Yogyakarta: Pustaka Pelajar.

Ismaimuza, D. (2010). The Effect of Problem Based Learning with Cognitive Conflict Strategies on Mathematical Critical Thinking Ability and Attitudes of Junior High School Students. Jurnal Pendidikan Matematika UNSRI, (Online), Vol. 4 No. 1

Jihad, A. (2008). Mathematics Curriculum Development. Yogyakarta: Multi Pressindo.

Julita. (2014). Developing Mathematical Critical Thinking Skills through Concept Achievement Learning. Proceedings of the National Seminar on Mathematics Education for the Postgraduate Program of STKIP Siliwangi, Nov:27. Bandung.

Mandur, K. (2013). Contribution of Connection Ability, Percentage Ability, and Mathematical Disposition on Mathematics Learning Achievement of Private High School Students in Manggarai Regency. E-Journal PPs Universitas Pendidikan Ganesha. Vol. 2. Thn. 2013. Halaman: 4.

Muijs, D., \& Reynolds, D. (2005). Effective teaching evidence and practice. London: SAGE Publications.p.212.

Mulyadi. (2010). Diagnosis of Learning Difficulties and Guidance on Specific Learning Difficulties. Yogyakarta: Nuha Litera.

Mulyasa, E. (2007). Competency Standards and Teacher Certification. Bandung: Remaja Rosdakarya.

Riyanto, Y. (2010). New Paradigm of Learning. Jakarta: Kencana Prenada Media Group.

Sakerebau, J. (2018). Memahami Peran Psikologi Pendidikan Bagi Pembelajaran. BIA: Jurnal Teologi dan Pendidikan Kristen Kontekstual 1.1, hal 96-111. 
Sauri, S. (2006). Building Communication in the Family. Bandung: PT Genesindo.

Shadiq, F. (2014). Mathematics Learning (How to Improve Students' Thinking Ability). Yogyakarta: Graha Ilmu.

Siswanto, \& B. Tri. (2016). Factors Influencing Student Learning Outcomes On Teaching Practical Automotive High School Schools in Yogyakarta City. Jurnal pendidikan vokasi. 6 (1): 2476- 9401.

Suherman.E, et al. (2003). Strategi Pembelajaran Matematika Kontemporer (Edisi Revisi). Bandung: JICA-Universitas Pendidikan Indonesia (UPI).

Sukardi, Ketut, D dan Kusmawati, N. (2008). Guidance and Counseling Process in Schools. Jakarta: PT Rineka Cipta.

Sumarmo, U \& Permana Y. (2007). Develop High School Students' Reasoning Ability and Mathematical Connection Through Problem Based Learning. Jurnal Educationist. Vol. I. No 2. page: 117.

Sumarwiyah. (2009). The Effect of the Application of Tutoring Services on Study Habits and Learning Achievement. Jurnal Sosial and Budaya. Vol:2 No 2.

Tilaar, H. A. R. (2012). National Education Kaleidoscope. Jakarta: Gramedia.

Trianto. (2010). Designing Innovative-Progressive Learning Models. Jakarta: Kencana Prenada Media Group.

Wardati \& Jauhar, M. (2011). Guidance and Counseling Implementation in Schools. Jakarta: Prestasi Pustakaraya.

Yusuf, S. (2005). Guidance and Counseling Foundation. Bandung: PT. Remaja Rosda Karya. 